\title{
人工地盤を想定した剛接合立体トラスの実験的研究 EXPERIMENTAL STUDY ON RIGID JOINT SPACE TRUSS ON THE APPLICATION TO AN ARTIFICIAL GROUND
}

\author{
小野徹 郎*, 対馬 義 幸**, 岩田 衛*** \\ Tetsurou ONO, Yoshiyuki TUSHIMA and Mamoru IWATA
}

\begin{abstract}
A large scale space truss for constructing an artificial ground above facilities, for example, a railroad track, a large river, existing buildings and so on, is required to have the capacity for supporting the heavy vertical load and also resisting the lateral load. In this paper, the mechanical behavior of the rigid joint space truss, which was developed to satisfy the required capacity, was experimentally investigated under vertical and lateral loading conditions. It is concluded that the space truss shows stable deformation behavior due to the re-allocation of stress and thus, that it possesses sufficient ultimate strength and plastic deformation capacity.
\end{abstract}

Keywords : space truss, lateral loading, load-carrying capacity, deformation capacity 立体トラス, 水平載荷, 保有耐力, 変形能力

1.はじめに

都市の高度利用需要に対する技術的解答の一つとし て，鉄道線路，河川等の既存の施設や環境を保全したま ま上部を有効活用して街をつくる大径間人工地盤が挙げ られる。人工地盤という言葉が一般に用いられるように なったのは比較的新しく，1970 年代になってからであ る1) 3)。それまでは人土土地と呼ばれることが多く, 1963 年に日本建築学会・都市計画部会で定義づけられ た。これによると，「建築はじめ各種都市施設，オープ ンスペース等のベースとなる半永久的な構築物であり, 地上数メートルから上の空中に強剛, かつ合理的な基礎 をもった大スパンの脚で支えられた巨大な 1 層または 2 層以上の平板である。としており，これが人工地盤に おける原点亡考えられる。

しかし，日本建築学会による定義以降，現在に至るま で人工地盤に対する確たる定義はなされていない。ほと んどの人工地盤がオープンスペースを主目的としての意 味合いで建設されており，上部に独立した建設物を上載 したものはほとんどない。建物自体は独立した基礎で支 えられ，上部構築物の支持構造物となっていないものが 多く，スパンも $10 \mathrm{~m}$ 程度のものが多い。

ここでいう人工地盤は，ある程度想定外の荷重の大き
さや荷重の作用位置に合理的に対応することを要求しよ うとするものである。また，既存の機能をできるだけ損 なわずに構築できる人工地盤として大径間化も重要な項 目である。したがって，本論文で対象とする人工地盤を 構造的側面において建築物の上載, および大径間化が可 能であることと定義した。

この大径間人工地盤を構築する構造として立体トラス 構造が考えられる。立体トラスは上載される鉛直荷重を 立体的に支持構造に伝達できるため，ある程度の荷重の 增減や集中荷重に対して合理的に対応できる構造であ る。このような人工地盤に立体トラスを用いる場合には 上弦材と下弦材の間隔であるトラスせいが極めて大き く，トラス内部空間を有効に利用できる部材レイアウト を採用する方が有利である。例えば内部空間のくぎりを 直方体として駐車場や倉庫, 居室等に使用できる空間と することである。これを満足するものとして写真一1に 示す四角錐立体トラスを採用した ${ }^{4), 55}$ 。この立体トラス の斜材は下弦材への投影面で重なり合う部材構成であ り，内部空間を有効に利用できるとともに，部材数と節 点数の少ない経済性に富む立体トラスの一つである。ま た，水平力に対して格子梁方式の場合には，上下弦材に 生じる軸力が水平力と直交する上下弦材の柱間における
本論文の一部は，文献 8)で発表している。

* 名古屋工業大学社会開発工学科建築学系 教授. 工学博士

** 竹中技術研究所 研究所長 - 博士 (工学)

*** 新日本製鐵 室長・工学博士
Prof., Dept. of Architecture Nagoya Institute of Technology, Dr. F 13.

Ta' nnaka Technical Research Laboratory, Dr. Eng.

Nippon Steel Corporation, Dr. Eng. 


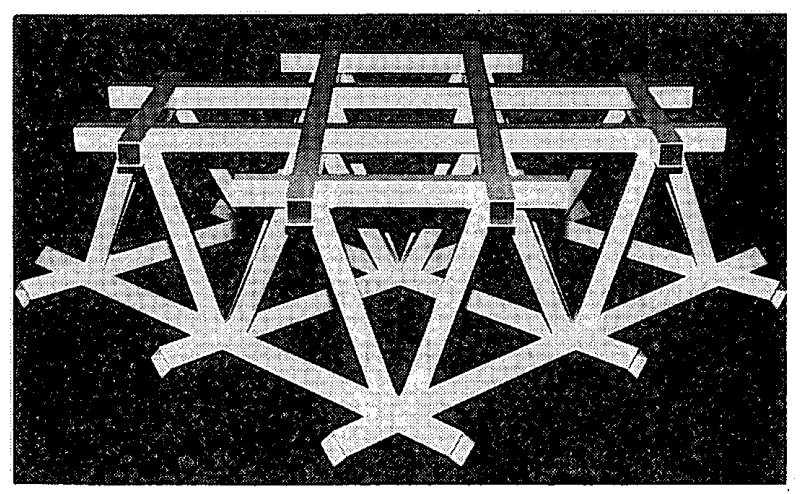

写真一1 四角錐立体トラスシステム

曲げ剛性により柱に伝達されるため, 構面内の剛性が小 さく，水平ブレースが不可欠である。しかし，四角錐立 体卜ラスの場合には下弦材に生じる軸力は下弦材と同じ 鉛直面内にある斜材を介して上弦材に伝達され，下弦材 と $45^{\circ}$ に交差する上弦材から軸力成分として柱に伝達さ れる。このように上弦材がブレース効果を持つため, 構 面内の剛性が大ききく，2次部材が不要となる。ただし， ピン接合トラスの場合には四角錐の相対回転により不安 定構造であることが明らかにされている(1),5)。ここでは， 周辺に梁を配置することにより相対回転を拘束するとと

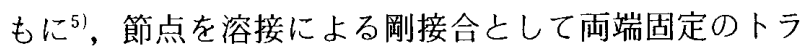
ス部材に置換することにより不静定次数を向上させて構 造の安定性を計っている4)。しかし，本立体トラスを地 震力に抵抗する人工地盤に適用するには塑性域における 挙動を明らかにする必要がある。

そこで，本論文では大きな鉛直荷重を支持する大径間 の四角錐で構成される実規模の剛接合立体卜ラス架構を 想定する。その想定構造物に対して鉛直載荷および水平 載荷による大規模な模型実験を行い，四角錐からなる剛 接合立体卜ラスの基本的な力学性状を明らかにするとと もに, 鉛直荷重分布状態が弾性域における変形や歪の変 動に及ぼす影響，あるいは水平荷重下における架構の個 材座屈の発生および個材座屈発生後の全体挙動を把握す るとともに, ‘接合部, 局部座屈等の関係でその耐力と勒 性などを検討し，この種の構造物の設計の可能性を示す ものである。

\section{2. 想定架構とモデル化}

\section{1 想定立体卜ラス架構}

想定した立体トラス架構の形状, 規模を図一1に示す。 本構造物は長辺長さ $378 \mathrm{~m}$, 短辺長さ $216 \mathrm{~m}$, そして高 さ $14.5 \mathrm{~m}$ の長方形大規模立体卜ラス構造物である。卜 ラスせい $7.5 \mathrm{~m}$ の剛接合立体トラスは, 長辺と短辺両 方向ともスパン $54 \mathrm{~m}$ の柱によって支持されている。こ こに，4本の柱に囲まれる部分を立体トラスの 1 ユニッ トと称する。1 ユニットの下弦材は $3 \times 3$ のグリッドを 構成し，1グリッドの大きさは $18 \mathrm{~m} \times 18 \mathrm{~m}$ である。構

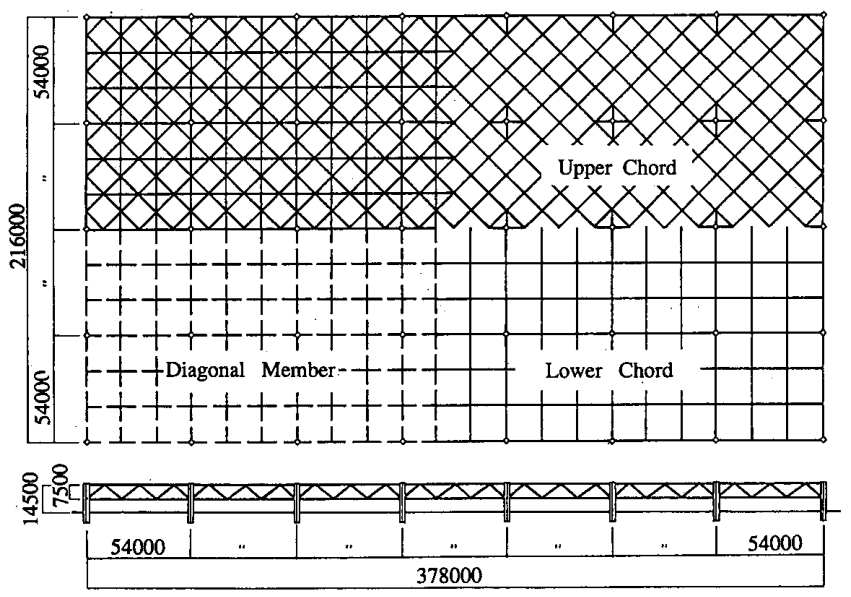

図-1 想定立体トラス架構
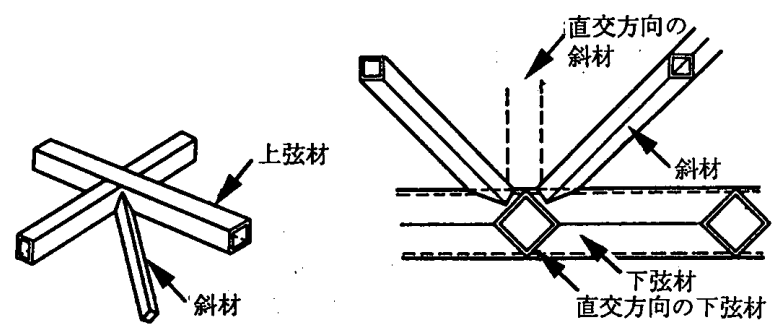

図一2 接合部モデル

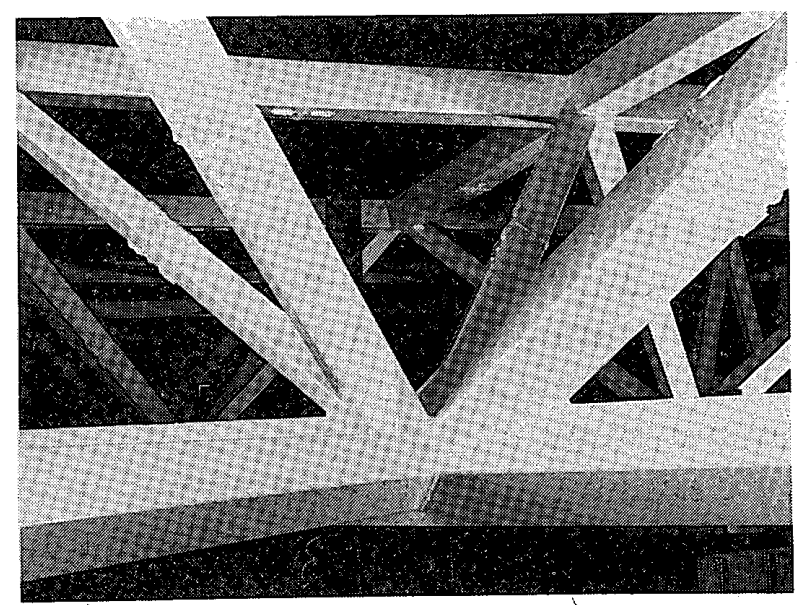

写真 -2 溶接接合部の外観

成部材は，座屈耐力が高く，大きなグリッドが構成でき る角形鋼管である。下弦材および斜材は材の軸線回りに $45^{\circ}$ 回転した菱形断面形状と ${ }^{9 !}$, 上弦材は通常の正方形 断面形状をとする。図一2 の接合部のモデル図に示すよ うに,下弦材および上弦材は一方向を通し材としている。 そのため，接合部における各材の交差線は材軸に直角に 切断した切り口の周長よりも長くなり，接合部を隅肉仕 様の溶接接合とすることができる8〉。また，大きい鉛直 荷重を支持できる大径間立体トラスを構成することが可 能となった。写真一2に溶接接合による接合の状況を示 す。表一1に想定構造物の各構成部材の断面寸法を示す。 この断面寸法の算定に当たっては, 鉛直荷重 $1.6 \mathrm{t} / \mathrm{m}^{2}$ と 水平荷重 $1 \mathrm{G}$ を受ける場合を想定して許容応力度設計 により設計した。トラス個材の細長比は, 各個材が堕性 
表一1 想定立体トラス架構と試験体の断面寸法

\begin{tabular}{|c|c|c|c|c|c|c|c|c|c|c|c|}
\hline \multirow{2}{*}{\multicolumn{2}{|c|}{\begin{tabular}{|c|} 
Assortment \\
1 \\
(an)
\end{tabular}}} & \multicolumn{3}{|c|}{ Hypothotic Kenber } & \multicolumn{2}{|c|}{ Ideal Meaber } & \multicolumn{5}{|c|}{ Application Member } \\
\hline & & $\begin{array}{l}\text { Porn of } \\
\text { Soction }\end{array}$ & \begin{tabular}{|l|}
$A\left(\mathrm{co}^{2}\right)$ \\
$\mathrm{i}(\mathrm{c})$ \\
\end{tabular} & 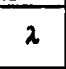 & $\begin{array}{l}\text { Porn of } \\
\text { Section }\end{array}$ & \begin{tabular}{|l}
$A\left(c^{2}\right)$ \\
$i(c m)$
\end{tabular} & $\begin{array}{c}\text { Pore of } \\
\text { Section }\end{array}$ & \begin{tabular}{|l|}
$1\left(\mathrm{~cm}^{2}\right)$ \\
$i(\mathrm{~cm})$ \\
\end{tabular} & - & $\begin{array}{c}1 \\
(\mathrm{mn}) \\
\end{array}$ & $d / t$ \\
\hline \multirow{3}{*}{$\begin{array}{l}\text { Lower } \\
\text { Chord } \\
18,000\end{array}$} & A & $750^{2} \times 18$ & \begin{tabular}{|c|}
537.5 \\
28.6 \\
\end{tabular} & 60.8 & $87.22^{2} \times 2.46$ & \begin{tabular}{|l|}
0.03 \\
3.84 \\
\end{tabular} & $100^{2} \times 4.5$ & \begin{tabular}{|r|}
16.67 \\
3.83 \\
\end{tabular} & 60.3 & \multirow{3}{*}{2333} & 22.2 \\
\hline & B & $1050^{2} \times 28$ & \begin{tabular}{|r|}
1110.8 \\
41.4 \\
\end{tabular} & 43.5 & $136.11^{2} \times 3.63$ & $\begin{array}{r}18.87 \\
5.36\end{array}$ & $150^{2} \times 6.0$ & $\frac{33.83}{5.84}$ & 38.8 & & 25 \\
\hline & C & $1050^{2} \times 32$ & \begin{tabular}{|r|}
1259.0 \\
41.2 \\
\end{tabular} & 43.7 & $136.11^{2} \times 4.15$ & $\frac{21.16}{5.34}$ & $150^{2} \times 6.0$ & \begin{tabular}{r|}
33.83 \\
5.84
\end{tabular} & 38.9 & & 25 \\
\hline \multirow{5}{*}{$\begin{array}{l}\text { Upper } \\
\text { Chord } \\
12,728\end{array}$} & D & $850^{2} \times 19$ & \begin{tabular}{r|}
613.4 \\
33.6
\end{tabular} & 37.8 & 110.1 & $\frac{10.31}{4.36}$ & $<4.5$ & $\frac{21.17}{4.89}$ & 33.8 & \multirow{5}{*}{1655} & 27.8 \\
\hline & D & $850^{2} \times 18$ & $\begin{array}{r}813.4 \\
33.6 \\
\end{array}$ & 37.8 & $110.18^{2} \times 2.46$ & \begin{tabular}{|r|}
10.31 \\
4.36 \\
\end{tabular} & $200^{2} \times 6.0$ & $\begin{array}{r}45.63 \\
7.88 \\
\end{array}$ & 22.4 & & 33. \\
\hline & $\mathbf{E}$ & $2 \times 25$ & $\begin{array}{r}788.1 \\
33.4 \\
\end{array}$ & 38.1 & $110.19^{2} \times 3.24$ & $\frac{13.41}{4.33}$ & $125^{2} \times 4.5$ & $\begin{array}{r}21.17 \\
4.89 \\
\end{array}$ & 33.8 & & 27.8 \\
\hline & F & $1450^{2} \times 40$ & \begin{tabular}{|r|}
2187.2 \\
57.1 \\
\end{tabular} & 22.3 & $187.98^{2} \times 5.18$ & $\begin{array}{r}38.75 \\
7.40\end{array}$ & $200^{2} \times 6.0$ & \begin{tabular}{r|}
45.63 \\
7.88 \\
\end{tabular} & 21.0 & & 33.3 \\
\hline & N & $850^{2} \times 28$ & $\begin{array}{r}888.8 \\
33.2 \\
\end{array}$ & 38.3 & 110.1 & $\frac{14.84}{4.30}$ & 4.5 & $\frac{21.17}{4.89}$ & 33.8 & & 27.8 \\
\hline & $G$ & $550^{2} \times 16$ & $\begin{array}{r}330.8 \\
21.8 \\
\end{array}$ & 54.2 & $30^{2} \times 2.07$ & $\frac{5.56}{2.80}$ & $75^{2} \times 3.2$ & $\frac{8.82}{2.19}$ & 52.2 & & 23.4 \\
\hline & $\mathrm{H}$ & $550^{2} \times 25$ & \begin{tabular}{r|}
487.4 \\
20.9
\end{tabular} & 56.1 & $71.30^{2} \times 3.24$ & $\frac{8.19}{2.71}$ & 1.5 & \begin{tabular}{r|}
18.67 \\
3.87
\end{tabular} & 38.3 & & 22.2 \\
\hline & I & $550^{2}$ & \begin{tabular}{r|}
537.0 \\
20.7
\end{tabular} & 56.6 & 71.3 & $\frac{9.02}{2.68}$ & 100 & \begin{tabular}{r|}
16.87 \\
3.87
\end{tabular} & 39.3 & 1518 & 22.2 \\
\hline & $J$ & $1050^{2} \times 40$ & \begin{tabular}{|r|}
1547.2 \\
40.7 \\
\end{tabular} & 28.8 & $138.11^{2} \times 5.18$ & $\begin{array}{r}28.00 \\
5.28\end{array}$ & $150^{2} \times 5.0$ & $\frac{28.38}{5.89}$ & 25.8 & & 30 \\
\hline & $\mathbf{K}$ & $1250^{2} \times 40$ & \begin{tabular}{|r|}
1867.2 \\
48.9 \\
\end{tabular} & 24.0 & $162.04^{2} \times 5.18$ & $\frac{31.38}{8.34}$ & $175^{2} \times 6.0$ & $\frac{39.63}{8.86}$ & 22.1 & & 29.2 \\
\hline $\begin{array}{l}\text { Strut } \\
7,500\end{array}$ & $\mathbf{M}$ & $2250^{2} \times 80$ & \begin{tabular}{|r|}
6668.8 \\
87.6 \\
\end{tabular} & 8.6 & $291.67^{2} \times 10.37$ & \begin{tabular}{|r|}
112.06 \\
11.36
\end{tabular} & $450^{2} \times 22$ & \begin{tabular}{|c|}
344.2 \\
18.9
\end{tabular} & 5.7 & 871 & 20.5 \\
\hline \begin{tabular}{|l|} 
Column \\
15,000 \\
\end{tabular} & $M$ & $2250^{2} \times 80$ & \begin{tabular}{|r|}
6668.8 \\
87.6 \\
\end{tabular} & 17.1 & $281.67^{2} \times 10.37$ & \begin{tabular}{|r|}
112.06 \\
11.36 \\
\end{tabular} & $450^{2} \times 22$ & \begin{tabular}{|r|}
344.2 \\
16.8 \\
\end{tabular} & 13.0 & 1100 & 20.5 \\
\hline
\end{tabular}

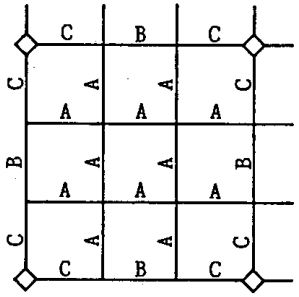

Lower Chord

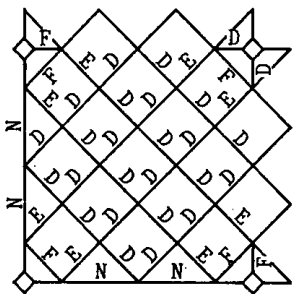

Upper Chord

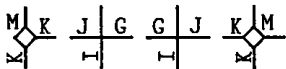

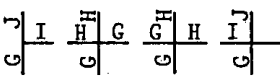
of $I \frac{H^{0}}{x} \frac{C^{2}}{G^{2}} \frac{\mathrm{I}}{\mathrm{I}}$

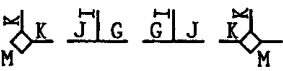

Diagonal Member

図一3 各卜ラス個材名称
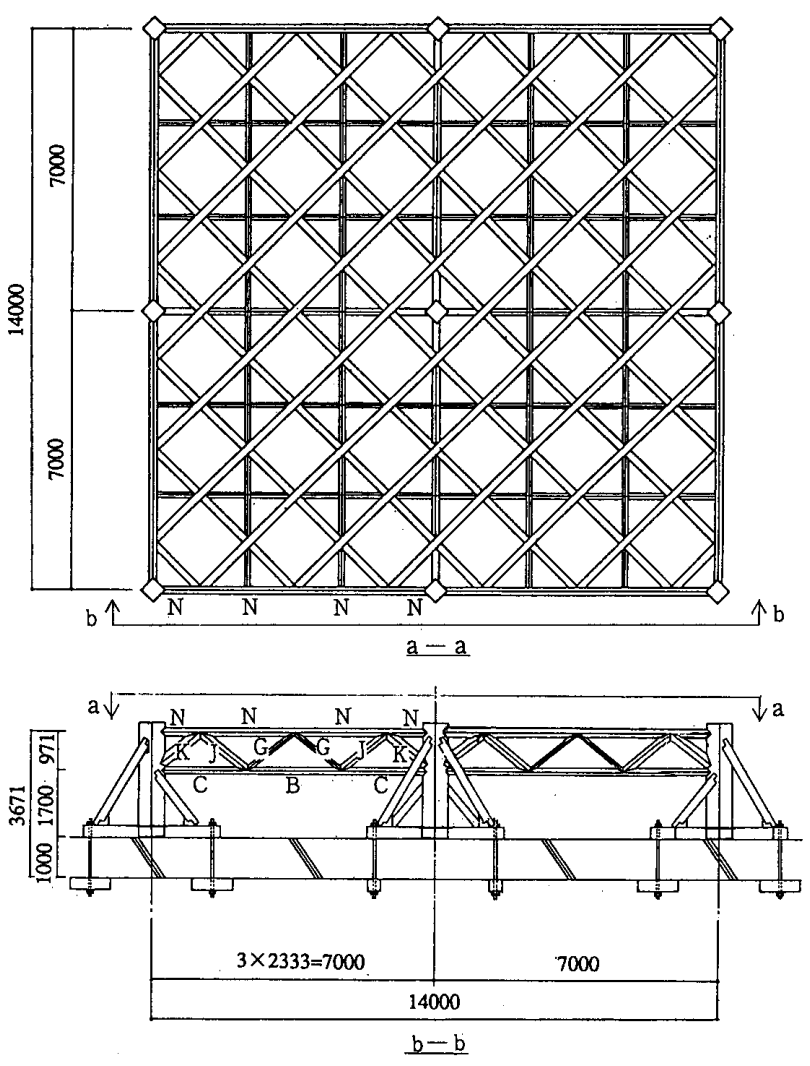

図一4 剛接合立体トラス架構試験体

化後に曲げ座屈するように現行基準のブレースの構造ラ ンクに示される細長比を参考にして 22〜61を用い，大 きな鉛直荷重を支持できるように設計している。このよ うに設計された想定構造物での崩壊は個材の曲げ座屈が

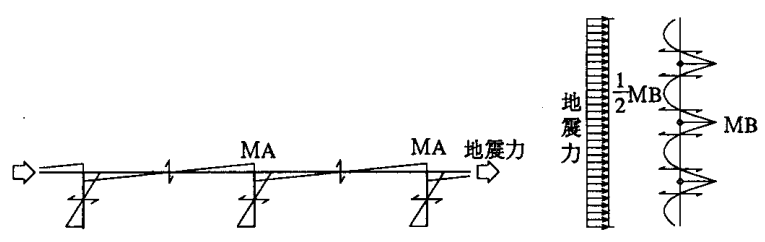

（a）想定構造物の地霆時応力分布（立面）

（c）想定構造物の地震 時応力分布 (平面)

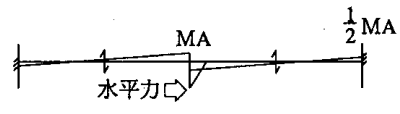

（b）中柱加入力する水平力に対す る応力分布 (立面)

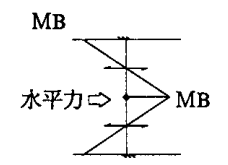

（d）中柱から入力する水平力 に対する応力分布 (平面)

図一5 忘力分布のモデル図

先行するものである。表一1 中の各部材の配置を図一3 にアルファベットで対応させて示す。

\section{2 試験体のモデル化}

実規模の想定構造物の大きさが 1 ユニット当たり平面 で $54 \mathrm{~m} \times 54 \mathrm{~m}$, トラスのせい $7.5 \mathrm{~m}$ である。試験体は, 実験施設および載荷機器の関係から $2 \times 2$ ユニットとし, 接合部における現実の溶接仕様の制約より 1/7.7 の縮尺 率とした。下弦グリッド数 $3 \times 3$ で構成される 1 ユニッ 卜を 4 ユニット分組み合わせた試験体を図一 4 に示す。 この試験体の水平載荷時の応力分布は想定構造物の柱周 辺の応力状態に対応している。

図一5 は地震時に架構に作用する曲げモーメントとせ ん断力の反布の概念図である。(a) と（c）は想定構造 物に地震荷重が作用した場合の荷重方向, およびその直 交方向の曲げモーメント図である。ここで, 加力実験の 

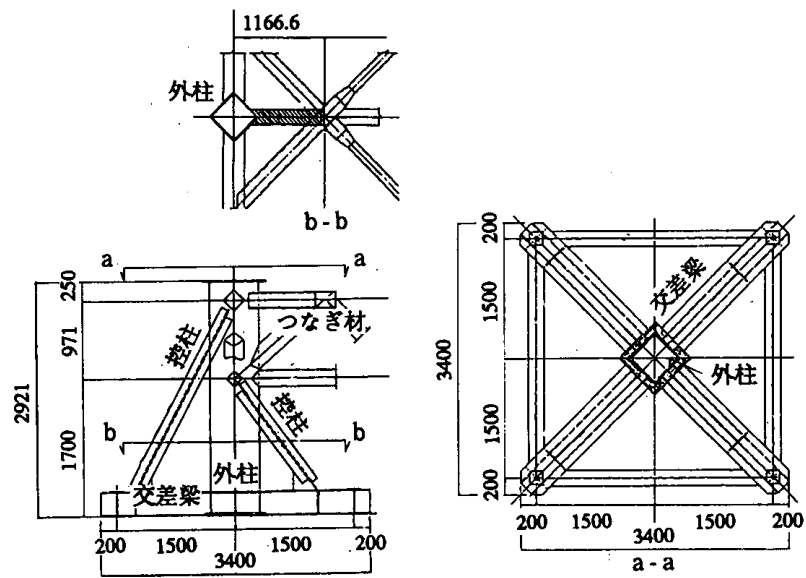

図一6 外柱の固定状況

表一2 材料の機械的性質

\begin{tabular}{|c|c||ccc||cr|}
\hline \multicolumn{2}{|c||}{} & \multicolumn{3}{c||}{ Tension Test } & \multicolumn{2}{|c|}{ Stub-Colum test } \\
\hline Base Metal & $\begin{array}{c}T \\
(\mathrm{~mm})\end{array}$ & $\begin{array}{c}\sigma \\
\left(\mathrm{t} / \mathrm{cm}^{2}\right)\end{array}$ & $\begin{array}{c}\sigma_{\mathrm{a}} \\
\left(\mathrm{t} / \mathrm{cm}^{2}\right)\end{array}$ & $\begin{array}{c}\mathrm{El} \\
(\%)\end{array}$ & $\begin{array}{c}\sigma \\
\left.\left(\mathrm{t}^{2}\right)^{2}\right)\end{array}$ & $\begin{array}{c}\sigma_{\mathrm{v}} \\
\left(\mathrm{t} / \mathrm{cm}^{2}\right)\end{array}$ \\
\hline$\square-100 \times 100 \times 4.5$ & 4.23 & 3.822 & 4.578 & 34.28 & 3.77 & 4.07 \\
$\square-150 \times 150 \times 6.0$ & 5.61 & 4.007 & 4.789 & 33.20 & 3.63 & 3.91 \\
$\square-125 \times 125 \times 4.5$ & 4.09 & 4.039 & 4.739 & 32.86 & 3.68 & 3.85 \\
$\square-200 \times 200 \times 6.0$ & 5.56 & 3.921 & 4.759 & 34.22 & 3.62 & 3.67 \\
$\square-75 \times 75 \times 3.2$ & 3.08 & 4.124 & 4.801 & 28.86 & 4.38 & 4.63 \\
$\square-175 \times 175 \times 6.0$ & 5.65 & 4.100 & 4.923 & 32.28 & 3.93 & 4.06 \\
\hline
\end{tabular}

ためのモデル化として 4 ユニットを取り出し，(b) と (d) に示すように，外周柱を固定して中柱から水平力により 立体トラスに曲げとせん断力を加えることとした。中柱 に対する影響領域を 1 ユニット分と考えれば, 中柱周辺 の影響領域における荷重方向およびそれと直交方向の モーメント勾配は想定構造物より小さい。しかし, 中柱 近傍のトラス個材へ導入される応力は想定構造物にほぼ 対応し，その領域の座屈により規定される試験体の耐力 も想定構造物に対応している。曲げが卓越するような大 径間想定構造物の場合には, 中柱位置周辺の立体卜ラス 上下弦材に生じる軸力は，モーメント勾配の小さい方が 大きな軸力が導入されることになる。したがって，本実 験で得られる結果は安全側評価となる。

そこで，図一4に示す試験体の外周柱の柱脚部を反力 床に緊結された交差梁上に剛接合し，柱上部を交差梁上 に設置した控柱で緊結して固定条件を満足するものとし た。図一6に外柱の設置状況を示す。実験時の破壊モ一 ドを柱崩壊型でなくトラス崩壊型にすることを主眼とし て，柱断面の縮尺率は $1 / 5$ とした。試験体の構成部材の 角形鋼管は, 先に示した $1 / 7.7$ の縮尺率にできるだけ近 づけるように断面積および細長比を考慮して選択した

(表一 1 参照)。縮尺した理想部材と試験体部材の断面 寸法を表一1に示す。角形鋼管の幅厚比は局部座屈に対 して十分な変形能力を有するものを採用した。表一 2 に 試験体の材料の機械的性質を示す。使用鋼材はすべて STKR 400 とした。写真一 3 は試験体の外観である。

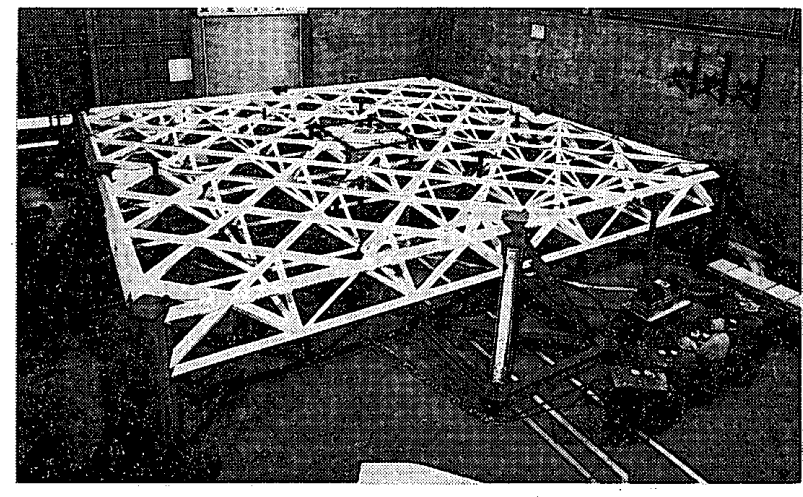

写真一3 試験体の外観

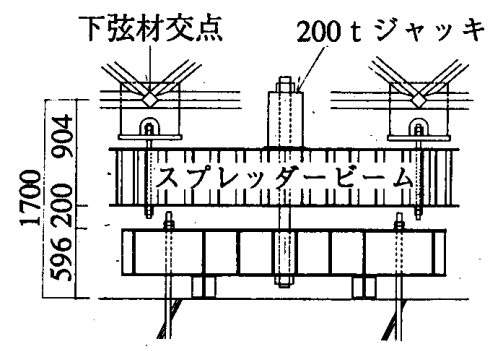

図一7 鉛直載荷治具

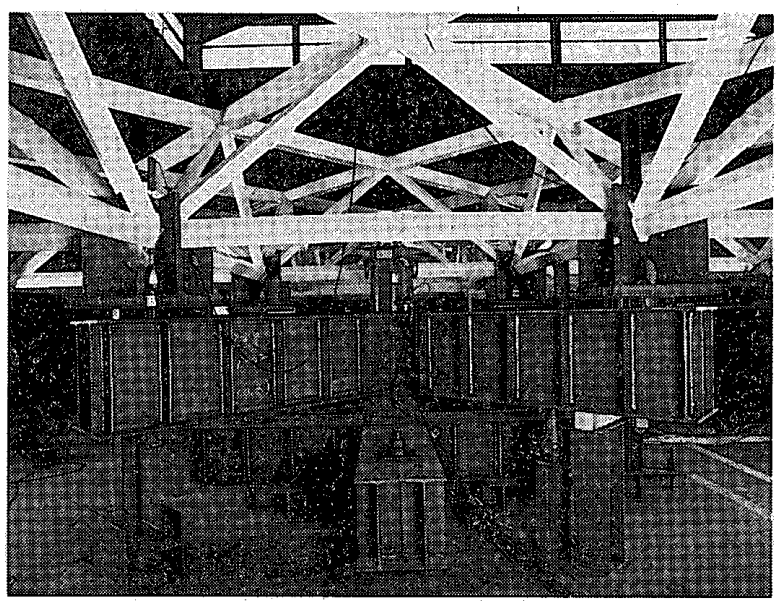

写真一4 鉛直載荷治具外観

3. 加カシステム

\section{1 鉛直載荷}

鉛直載荷実験は，最大荷重の大きさを長期荷重とし， 立体トラスの 1 ユニットごとの載荷領域の増加に伴う変 形，応力の推移を検討することを目的としている。鉛直 荷重は，柱に接合される下弦材を除く各ユニットの下弦 材の 4 交点を 1 組として, 各交点に均等に作用するよう にスプレッダービームを用いて載荷した。図一7 と写真 一4にそれぞれ載荷治具とその外観を示す。油圧ジャッ キは各ユニット 1 台とし, 計 4 台を用いた。各ユニット の載荷ステップは, トラス自重と長期荷重の合計 1.6 $\mathrm{t} / \mathrm{m}^{2}$ に相当する $80 \mathrm{t}$ を $20 \mathrm{t}$ ずつ 4 ステップとした。図 一8に示すように, ユニット 1 から順次最大荷重 $80 \mathrm{t}$ ま で加力して保持し，最終的に 4 ユニットに均等に作用さ せた。 


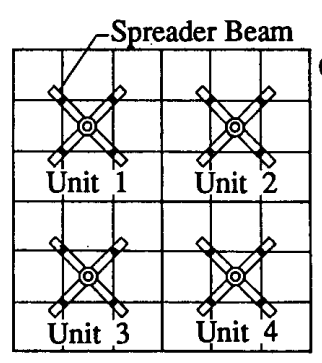

(O) -- Jack

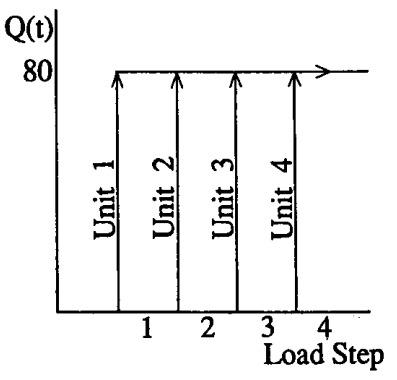

図一8 鈆直加力計画

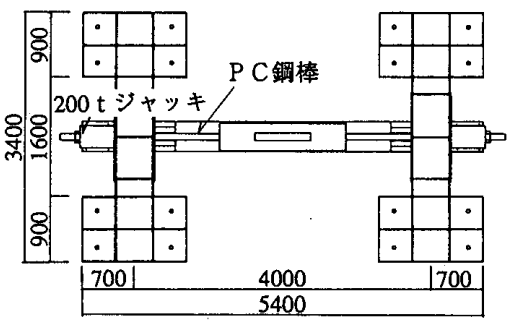

(b) 平面図

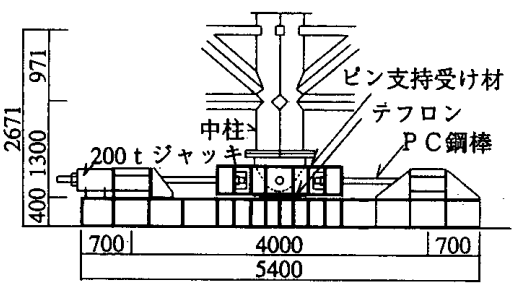

(a) 立面図

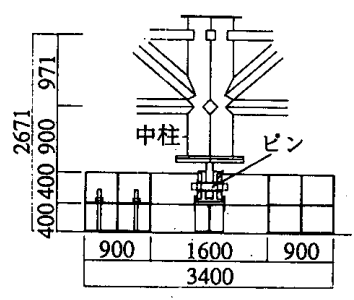

(c) 㑡面図

\section{2 水平載荷}

本実験では，鉛直載荷実験の最大荷重を載荷した状態 で水平力を単調に加え, 細長比と幅厚比の小さい部材で 構成される剛接合立体卜ラス架構の弾塑性変形性状を把 握することを目的としている。地震力により立体トラス 架構に生じる曲げモーメントとせん断力は中柱に水平荷 重を加えることにより導入するため, 地震荷重に対する 反曲点位置を考慮して中柱の長さを $1 / 2$ とした。その下 部をローラー支持として，ピン位置を水平荷重の載荷位 置とした。水平荷重は, 下弦材と平行な方向に作用させ た。中柱下端のピン支持受け材である $\mathrm{H}$ 形鋼の下部にテ フロンを敷き，ローラー支持条件を再現した。この $\mathrm{H}$ 形 鋼を $\mathrm{PC}$ 鋼棒を介して油圧ジャッキに接続して水平荷

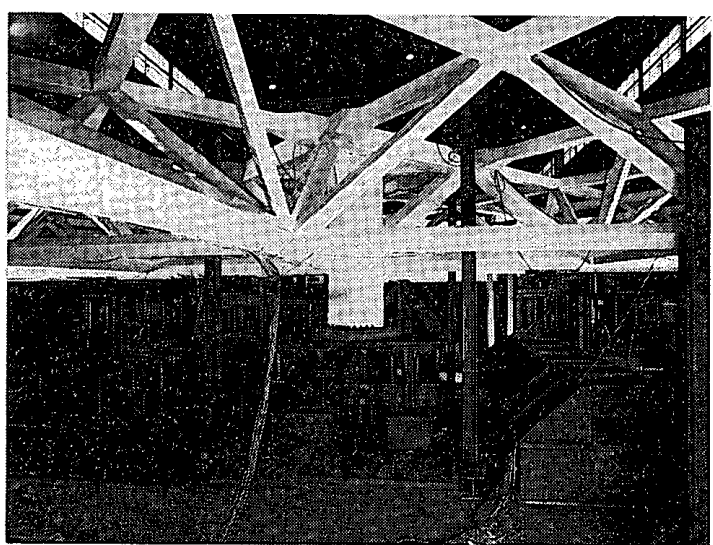

写真一5 水平載荷治具外観
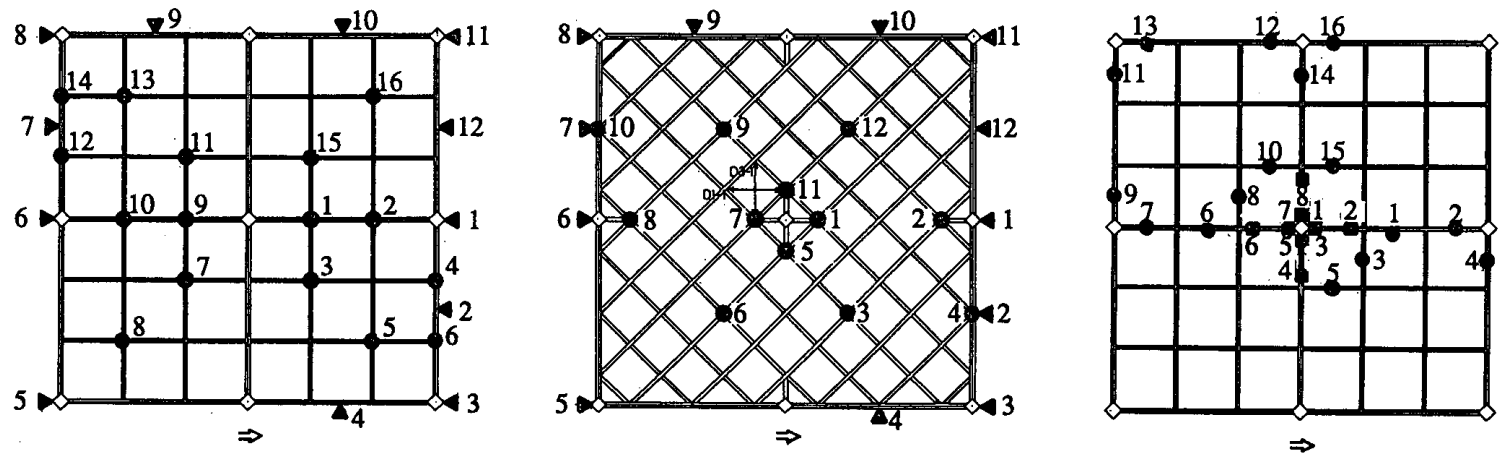

$\mathrm{B} 1-\alpha, \alpha=1 \sim 12 \bigcirc \mathrm{C} 1-\beta, \beta=1 \sim 16$

(a) 下弦材変位計位圆

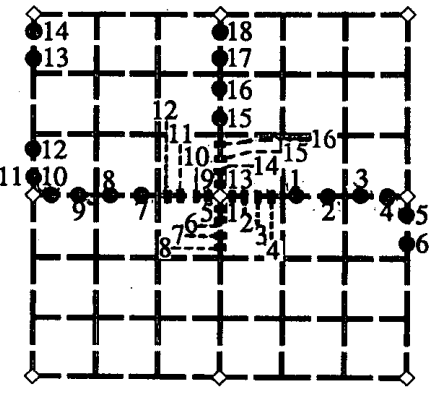

$\Rightarrow$

$\square_{\mathrm{F} 2}-\alpha, \alpha=1 \sim 16 \bigcirc \mathrm{G} 2-\beta, \beta=1 \sim 18$

(d) 斜材ひずみゲージ位圈
B3 $-\alpha, \alpha=1 \sim 12 \odot \mathrm{C} 3-\beta, \beta=1 \sim 12$

(b) 上弦材変位計位置

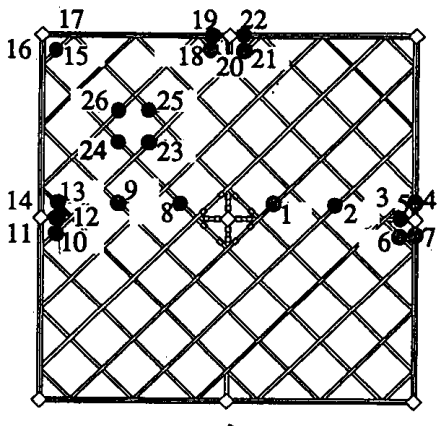

G3 $-\beta, \beta=1 \sim 26$

(e) 上弦材ひずみゲージ位固

図一10 変位と歪の計測位置

\section{B : 水平変位形番号 \\ C : 鉛直変位形番号 \\ $\mathrm{F} \sim \mathrm{G}:$ 䄳ゲージ番号}


重を加えた。本試験体の設計荷重は，水平荷重を $1 \mathrm{G}$ として $80 \mathrm{t}$ である。水平載荷治具を図一9に示す。また, 写真一 5 は中柱下部の載荷装置の外観である。なお，鉛 直載荷時には中柱下部の水平移動を拘束した。

\section{3 測定計画}

荷重は，鉛直載荷用の各ユニットごとのジャッキおよ び水平載荷用のジャッキに接続した油圧計により検出し た。変位は，上下弦面における部材の交点部の上下方向 変位, 中柱および外柱の水平変位を変位計により測定し た。部材の歪は, 主に軸歪を対象としたものと曲げ歪を 対象とした 2 種類を歪ゲージにより計測した。なお，鉛 直・水平載荷実験とも計測点は同じである。水平載荷時 には鉛直載荷における残留変形, 歪を累加して計測した。 図一 $10(a),(b)$ は変位, (c)～（e）は歪の計測位置を 示す。英記号 $\mathrm{B}$ は水平変位計番号, $\mathrm{C}$ は鉛直変位計番号, $\mathrm{F}$ は曲げ歪計測用の歪ゲージ番号，そして G は軸歪計測 用の歪ゲージ番号である。

\section{4. 鉛直載荷性状}

柱 4 本で囲まれる 1 ユニットごとに順次鉛直荷重を作 用させ, 偏分布荷重状態における鉛直変形と軸歪の変動 を調べた。

\section{1 鉛直変形}

図-11 は鉛直荷重と上下弦材交点の鉛直変位の関係

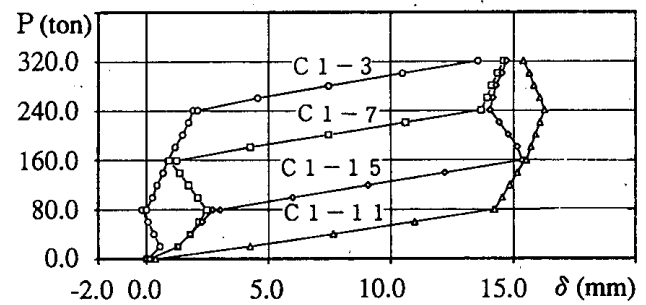

(a) ユニット中央部下弦材交点

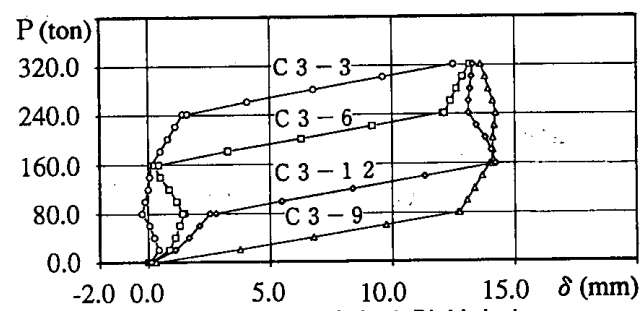

(b) ユニット中央部上弦材交点

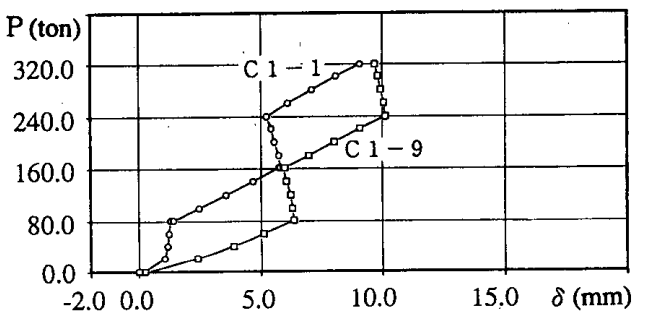

(c) エニット境界上の下弦材交点

図-11 鉛直荷重一鉛直変位関係
を示す。縦軸は各ユニットに順次作用する鉛直荷重の 和, 横軸は鉛直変位である。下向きの変位を正とした。 (a) と（b）は，それぞれ各ユニット中央部の下弦と上 弦の鈶直変位である。上下弦とも, 加力される時のユニッ トの鉛直方向の㴊性は加力ステップに対して線形であ り, 変位量之剛性は加力順序にかかわらず等しい。加力 されるユニット（例えばＣ1-11 の場合）亡中柱に対し て, 点対称にあるユニット（C 1-3）の変位方向は逆転 し，隣合うユニット（C 1-7, C 1-15) の変位方向は同 じである。ユニットに鈶直荷重が作用すると変位の変動 は大きいが，他のユニットに荷重が作用したときには変 位の変動は少なく，ユニット相互の影響は小さい。最終 的に全ユニットに荷重が作用すると，立体トラス架構と 荷重の対称性からそれぞれ 4 点の変位は等しくなる。(c) は 1,3 亡 2,4 のそれぞれのユニットの境界上にある下 弦材交点の鉛直変位である。境界上の交点は, 片側の工 ニットに荷重が加わると変形を増大させ，両側のユニッ

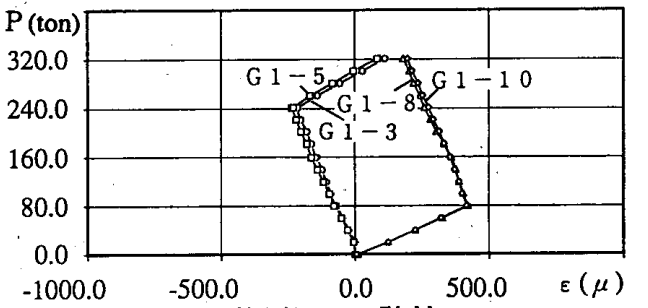

(a) 中柱周辺の下弦材

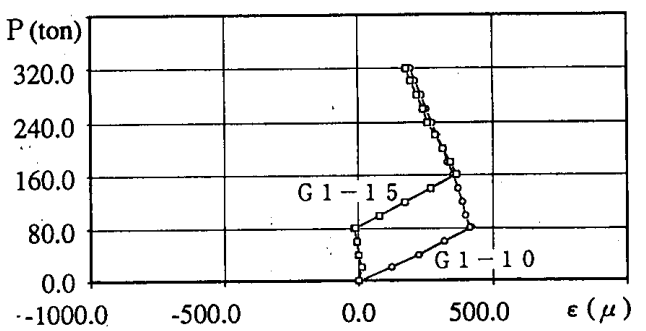

(b) 中柱周辺の下弦材

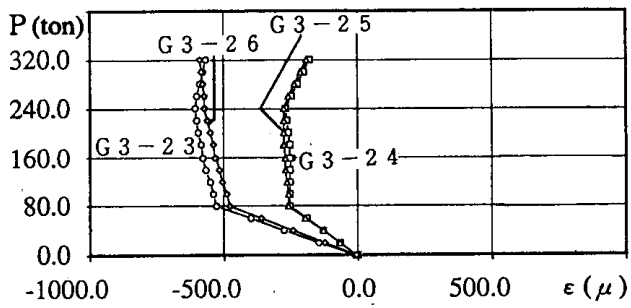

(c) ユニット中央部の上弦材

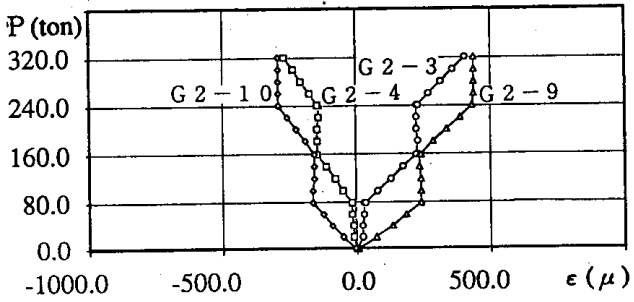

(d) ユニット境界上の斜材

図一12 鉛直荷重一軸䄳関係 
トに荷重が作用した時にも同じ剛性で変形を増大させる が，他のユニットからの影響は小さい。

\section{2 歪の変動}

図一 12 はトラス個材の荷重一軸歪関係である。(a) と（b) は中柱から等しい距離にある下弦材の軸歪であ る。当該ユニットに荷重が作用すると引張方向の歪が増 大し，その他のユニットに荷重が作用する時には逆曲げ 状態となって王縮方向に増大し，ユニット相互の影響が 見られる。（c）はユニット1の中央部における上弦材軸 歪の変動を示す。ユニット 1 が初めに載荷されて軸歪が 増大するが，他のユニットに荷重が作用する場合には歪 の変動は小さい。(d) はユニット間の境界上にある斜 材の軸歪である。この斜材を境界上に有するユニットに 荷重が作用すると軸歪が増大し，その他のユニットに荷 重が作用する場合にはほとんど軸歪は変動しない。これ より，鉛直荷重の作用位置によるトラス個材の軸歪の変 動に及ぼすユニット間の影響は上弦材と斜材に対してほ とんど見られないが，下弦材に対しては顕著である。ま た，この場合には全ユニットに荷重が加わった等分布荷 重状態よりも偏分布荷重状態の方が軸歪が大きくなり， 最終荷重状態のみでは危険側評価となることを示してい る。

\section{5. 鉛直荷重作用下における水平載荷性状}

\section{1 水平変形}

図一13 は，中柱下部に入力した水平荷重とその位置 における水平変位の関係を示したものである。荷重が $90 \mathrm{t}$ 超えたあたりから変形が大きくなり，150 t 付近 で耐力低下した。この時, 図中に示す下弦材の(1)部材が 個材座屈したのが観察された。しかし, 変形の増大に伴 い $140 \mathrm{t}$ 位で再び耐力が徐々に上昇した。最大耐力時 (P 2) に対応する弾性変形を降伏変形 $\left(\delta_{y}\right)$ と考えれば, その 7 倍程度まで変形しても耐力の低下は認められず, 十分な塑性変形能力がある。これより，剛接合立体卜ラ スの保有水平耐力はせん断力係数で 1.8 程度の值が得ら れ，かつ， 6 以上の塑性変形能力を示し，耐力的にも変 形能力的にも十分な性能を有することが分かる。

\section{2 鉛直変形}

図一14 は水平荷重之上下弦材交点の鉛直変形の関係

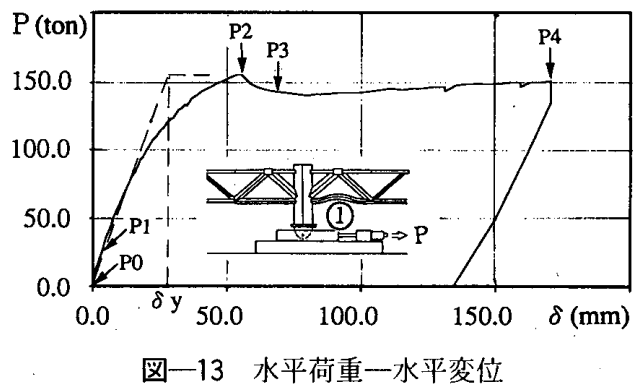

である。（a）に示す加力面内にある中柱に隣接する上弦 材交点の鉛直変位は，その交点が中柱と接合される強固 な斜材および中柱柱頭に接合されるつなぎ材に接合され ており, 中柱上部の回転変形に従い上下方向それぞれ逆 の動きを示している(下向き正方向)。(1)部材が個材坐 屈した後もほぼ対称に変形しており，中柱から立体卜ラ ス架構に曲げ変形が導入されている。(b)，(c) はそれ ぞれユニット 1 と 2 の中央付近の下弦材および上弦材交 点の鉛直変位と水平荷重の関係である。最大耐力までは, 各ユニット中央部の上下弦材交点の鉛直変位は中柱に対 して上下方向逆向きにほぼ対称な動きをしている。しか し, 最大耐力後さらに変形を進行させると, 加力方向之 逆側ユニット 1 の下向きの鉛直変位はさらに増大する が，加力側ユニット 2 の上向きの鉛直変位はほとんよ゙変

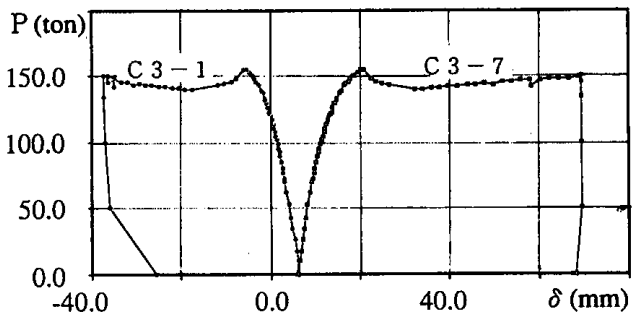

(a) 中柱に接する上弦材交点

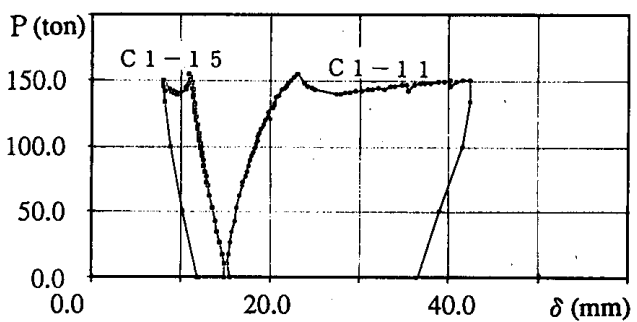

(b) エニット中央近傍の下弦材交点

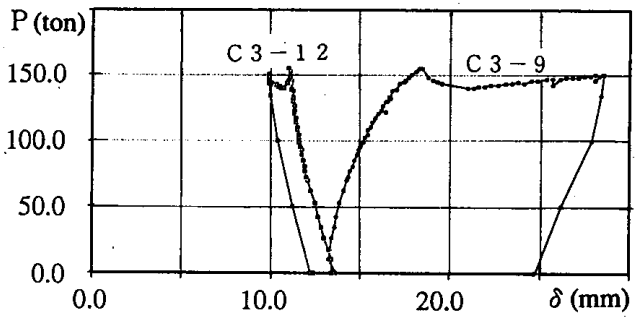

(c) ユニット中央近傍の上弦材交点

図-14 水平荷重一鉛直変位関係

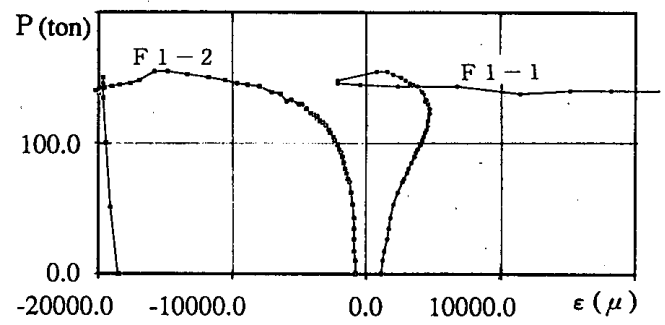

図一15 水平荷重一曲げ歪 

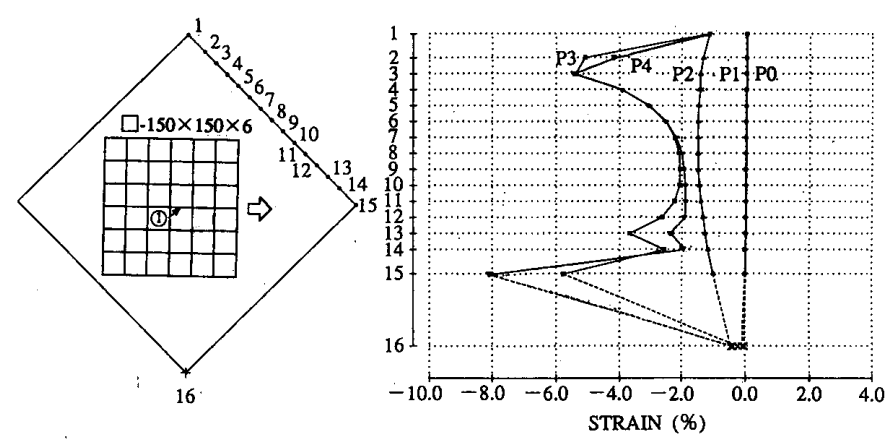

(a) 下弦材
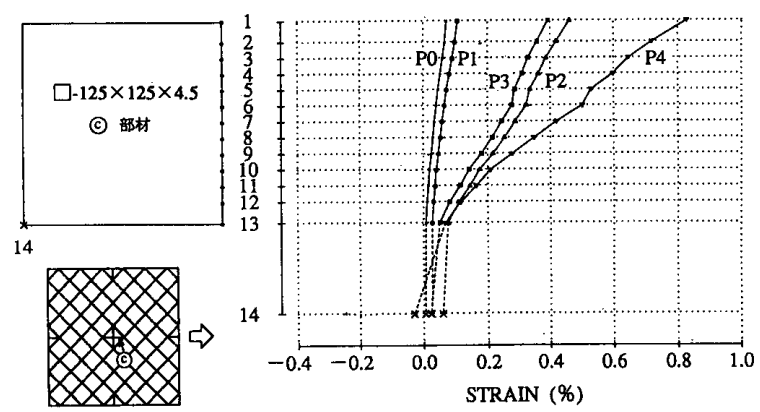

（b）上弦のつなぎ材

図一16 水平載荷時の集中歪分布

化しない。これは，中柱からの水平力に対して圧縮を受 け持つ(1)部材が曲げ座屈したことにより，中柱の回転変 形が加力側に進行しなくなったことを示す。応力伝達機 構としては, (1)部材が立体トラスの最大耐力を決定する 部材となったが，上弦材に流れる力が斜材を介して下弦 材へ伝達されるように変化し，立体トラスの耐力が保持 されていると考えられる。

\section{3 歪の変動}

図一15 は，水平荷重と曲げ座屈した(1)部材の曲げ歪

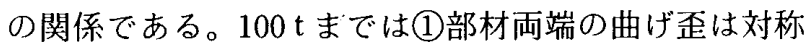
に生じているが，100 tで既に $2000 \mu$ を超えて塑性化し ている。さらに荷重を增大させると中柱側の曲げ歪は方 向を逆転し, 複曲率的な変形を生じている。曲げ座屈後, 局部座屈を発生して耐力低下するが，中柱側の曲げ歪は 再び中柱からの強制変形により方向を元に戻して増大し ている。しかし，中柱と反対の曲げ歪は耐力低下後ほと んビ変動していない。

図一16の (a) と（b) は，それぞれ中柱に接合され る加力方向側の下弦の(1)部材, および上弦のつなぎ材 $\mathrm{c}$ のそれぞれ中柱端の軸方向集中歪分布である。それぞれ 図一13 に示す P 0 P 4 の荷重点における分布を示す。 ゲージ番号を縦軸に示す。(1)部材の圧縮軸歪は, 最大耐 力までほぼ一様に変動し, 降伏歪の 10 倍程度に達して いる。耐力低下後のP 3 において隅角部に歪が集中し ており，曲げ座屈を生じてから局部座屈が発生したこと を示している。ここで(1部材がヒンジ状態になり，図一 15 で中柱と反対側の曲げ歪が変動しなくなったと考え

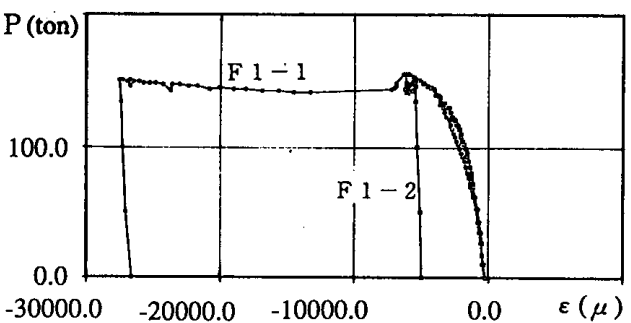

(a) (1)部材

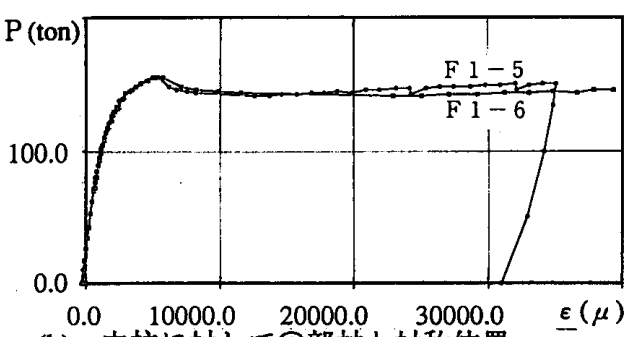

(b) 中柱に対して@部材と対称位置

図一17 水平荷重一軸歪関係

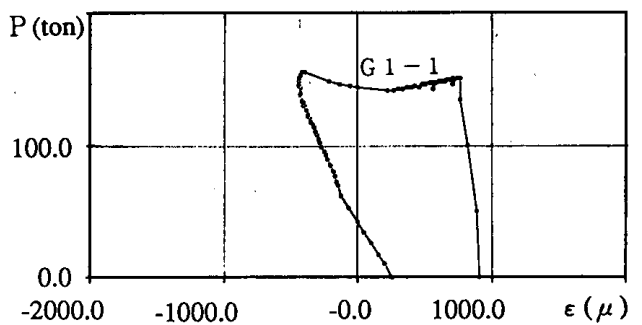

(a) 加力方向の下弦材

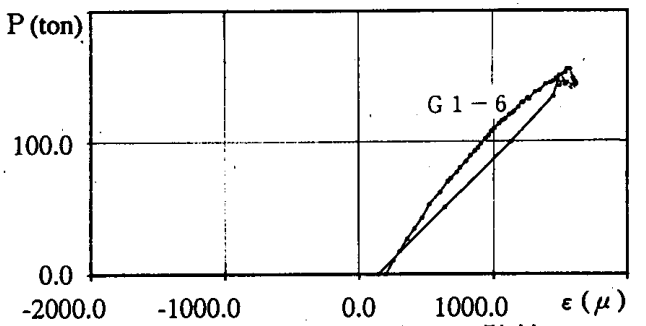

(b) 加力方向と反対側の下弦材

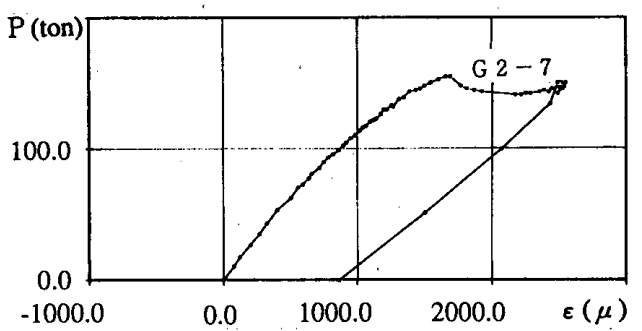

(c) 加力方向と反对側の斜材

图一18 水平荷重一軸歪関係

られる。一方，上弦のつなぎ材 c の引張軸歪は曲げ歪分 布を呈しながら増大している。耐力低下後 (P 2 $\rightarrow$ P 3), 若干歪の戻り現象が見られるが, 実験終了まで引張力を 負担している。

図一17 は中柱に接合される下弦材の軸歪に関して示 したものである。(a) は(1)部材の軸歪である。曲げ座屈 発生後は中柱側端部の圧縮歪は見かけ上増大している が, 反対側の圧縮歪は $700 \sim 800 \mu$ 程度昰除荷を呈して 


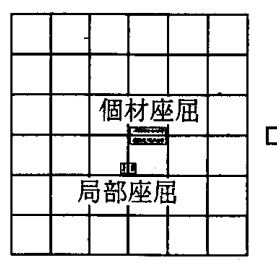

(a) 下弦材破壊分布

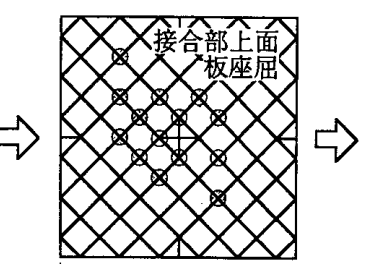

(b) 上弦材破壊分布

図一19 最終部材座屈状況

おり，軸力が低下していることがわかる。(b) は中柱 に対して曲げ座屈した(1)部材と反対側の部材の軸歪と水 平荷重の関係である。（a）と反対に，(1)部材の曲げ座屈 発生後は, 引張歪か湿著に増大しており, 歪硬化後の耐 力上昇分に対しても応力を負担している。

図一18 は中柱を含む加力方向の構面内にある下弦材 と斜材の軸歪の変動を示す。(a) は下弦材の曲げ座屈の 生じた(1)部材に連続する加力方向の部材の軸歪 (G 1-1) である。最大耐力に達するまで荷重増加に伴い圧縮歪が 増大するが，(1)部材の曲げ座屈の発生により軸歪が逆転 する。(b) に示す軸歪 (G 1-6) は, 中柱に対して (G 1-1) と反対位置にある部材の引張歪である。(1)部材の曲げ坐 屈発生後は, 歪の変動量はほとんどないが, 歪の反転が 見られる。(c) の軸歪 (G 2-7) は，(b) の部材の中柱 側端部に接合される斜材の軸歪である。(1)部材の曲げ座 屈発生後も引張丕が増大し，(b) の部材に対して応力 を負担している。さらに変形が増大すると, 歪の方向の 逆転が見られ, 変形の進行に伴う応力の再配分が順次起 きていることが伺われる。

\section{4 部材座屈状況}

図一19は，実験終了時における立体トラス部材の座 屈状況を示す。座屈箇所を四角または丸の黒塗で示す。 下弦材では，中柱に接合される加力方向の(1)部材の曲げ 座屈之，中柱に接合される加力方向と直交する部材端に 局部座屈変形がみられた。加力之直交方向の下弦材には 中柱から直接軸力は伝達されないが, 上弦材から斜材を 介して下弦材に圧縮力が伝達されて局部座屈変形が生じ たと考えられる。下弦材と $45^{\circ} に$ に交差する上弦材により 軸力が平面的に広がるため, 個材の塑性化が平面的に進 展することを示し，立体トラス全体の耐力に影響を及ほ している。上弦材では, 板座屈変形が中柱から広範囲な 領域に斜材の取り付かない接合部パネル上面にみられ た。写真一6(a) は(1)部材の局部座屈を伴う個材座屈変 形であり，写真一6(b) は上弦材の通し部材の接合部パ ネルの板座屈変形の 1 例である。この上うな座屈現象が 立体卜ラス架構の保有耐力を決定するが, 変形の増大之 ともにそれぞれの座屈が順次発生しても応力の再配分が 行われるため, 剛接合立体トラス架構は崩壊までには至 らない。

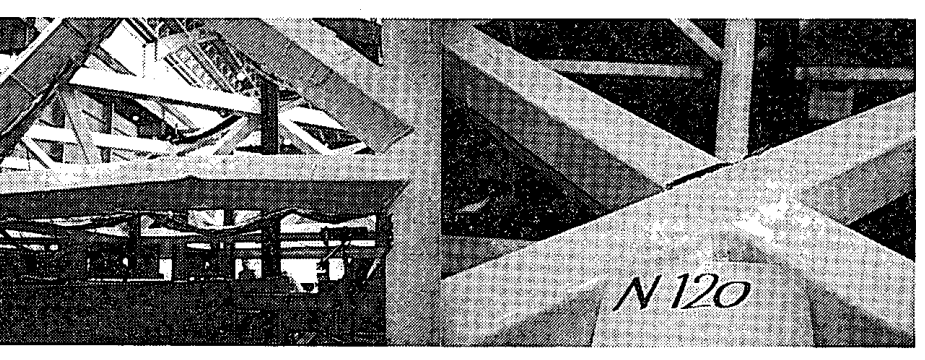

(a) (1)個材座屈

(b)，接合部板座屈

写真一 6 実験終了時の部材座屈外観

6. おわりに

大きな鉛直荷重を支持する大径間人工地盤を想定した 大規模な剛接合立体卜ラス架構の模型実験を行い，鉛直 荷重の作用位置を変化させた場合，さらに等分布鉛直荷 重が作用した状態で水平力を加えた場合の，剛接合立体 トラスの基本的な力学性状を把握した。以下に得られた 結果の要約を示す。

（1）長期荷重に相当する鉛直荷重を1 ユニットずつ順 次加える偏分布荷重状態において, ユニット相互の変形 や応力に及ぼす影響は小さい。ただし発生する変位, 歪 の最大値を把握するには，偏分布荷重が作用する場合に ついて検討する必要がある。

（2）鉛直荷重を一定に保持して, 中柱に載荷した水平 力により曲げモーメントとせん断力を生じさせた剛接合 立体卜ラスは, 下弦材の個材座屈によりいったん最大耐 力の $7 \%$ 弱酎力を低下させたが, 変形の進行に伴い徐々 に耐力を增大させて十分な塑性変形性能がある。

（3）中柱に接合された加力側のトラス個材の曲げ座屈 発生後, 加力上反対側のユニットの鉛直変位は加力点の 変形の進行とともに増大するが, 加力側ユニットの鉛直 変位はほとんど変化せず, 応力の伝達機構が変化する。 これは,トラス個材の軸歪の方向変化からも推定される。 （4）耐力低下後, 変形の進行に伴いトラス個材の曲げ 座屈, 局部座屈や上弦材接合部パネルの板座屈等が発生 する。しかし，不静定次数の高い剛接合立体トラスは, 応力の再配分が行われるために, 水平荷重に対しても大 きな塑性変形能力を有する。

以上よりここてで検討した剛接合立体トラス架構は, 大きな鉛直荷重やその作用位置に対してユニット間相互 の影響も小さく, また, 水平力に対して靱性が大きく, 大径間人工地盤の構築物として適用可能なことが明らか となった。

\section{謝 辞}

本研究を遂行するにあたり，(株) 竹中工務店 最上 公彦氏, 新日本製鐵(株) 武藤尤一氏, 日本大学 岡田 章助手より貴重なご助言を賜りました。記して謝意を表 します。 


\section{参考文献}

1）花輪 恒：都市と人工地盤一その意味と導入手法一, 鹿 島出版会, 1985.11.

2）（財）機械掁興協会 新機械システムセンター：層構造モ ジュールに関する調査研究, 1972.11.

3）（財）機械振興協会 新機械システムセンター：層構造モ ジュールに関する調查研究 (資料編)，1972.11.

4）加藤 勉, 高梨晃一, 対馬義幸, 平田康浩：四角錘によっ て構成される立体トラスの解析（第 1 報）”，日本建築学 会論文報告集，第 84 号, pp. 30 37, 1963.4.

5）加藤 勉, 高梨晃一, 対馬義幸, 平田康浩：四角鍾に上っ て構成される立体トラスの解析 (第 2 報)”, 日本建築学 会論文報告集，第 85 号，pp. 19２5，1963.5.

6）木村 衛，ほか 4 名：立体トラス人工地盤の力学挙動に ついてースペースLSY トラスー，アーバンインフラ・
テクノロジー推進会議, 第 2 回技術研究発表論文集, pp. 375 384, 1990.

7）最上公彦，ほか 3 名：立体トラスによる大径間人工地盤 計画例一スペース LSY トラス一，アーバンインフラ・ テクノロジー推進会議, 第 2 回技術研究発表論文集, pp. 593 598, 1990.

8）小野徹郎，ほか 9 名：剛接合角形鋼管立体トラスシステ 厶の実用化に関する研究（その1)（その 7)，日本建築 学会大会学術講演梗概集 (中国), pp. 1295 1308, 1990.

9）小野徹郎, 石田和人, 岩田 衛, 井戸田秀樹: Y 型接合 角形鋼管卜ラス分岐継手の疲労特性に関する実験的研究, 構造工学論文集, Vol. 38 B, pp. 443４49，1992.3.

(1993 年 6 月 4 日原稿受理, 1994 年 1 月 14 日採用決定) 